\title{
Secularization Theories and the Study of Chinese Religions
}

\section{Citation}

Szonyi, Michael. 2009. Secularization theories and the study of Chinese religions. Social Compass 56, no. 3: 312-327.

\section{Published Version}

doi:10.1177/0037768609338765

\section{Permanent link}

http://nrs.harvard.edu/urn-3:HUL.InstRepos:11130448

\section{Terms of Use}

This article was downloaded from Harvard University's DASH repository, and is made available under the terms and conditions applicable to Open Access Policy Articles, as set forth at http:// nrs.harvard.edu/urn-3:HUL.InstRepos:dash.current.terms-of-use\#OAP

\section{Share Your Story}

The Harvard community has made this article openly available.

Please share how this access benefits you. Submit a story.

Accessibility 


\section{Secularization theories and the study of Chinese religions ${ }^{1}$}

Michael Szonyi

Is China today a secularized society? Is it becoming more secularized, less secularized, or perhaps more desecularized? Unfortunately much of the scholarly discussion on such questions tells us less about the state of religion in China than it does about the preconceptions of the participants in the discussion. For such questions hinge on the meaning of the term secularization, and there is as yet no rigorous theory of secularization as it applies to China. The two disciplines that might have contributed to such a theory, sociology and the study of Chinese religions, have yet to hold the conversation necessary to produce it. ${ }^{2}$ Moreover, even when the two disciplines do engage one another, they typically do so using simplistic and out-dated perceptions of the other. When scholars of China invoke secularization, they often use the term in a sense that has largely been abandoned within sociology, namely that religion declines with modernization; little work on Chinese religion engages explicitly with current sociological literature on secularization. ${ }^{3}$ Similarly, while there is growing recognition within sociology of religion that processes of secularization are historically contingent and therefore that secularization may take many forms (Beckford 2003), the theoretical literature continues to be rooted in the specific historical experience of the West and makes little reference to China. This paper seeks to address this situation by relating, in a very preliminary and schematic way, some recent literature on Chinese religion in fields such as anthropology, history and political science to recent sociological literature on secularization theory. It also explores how ideas about secularization shape contemporary political discourse on religion in the People's Republic of China.

This paper covers some of the same terrain as Goossaert's analysis of paradigms in the study of Chinese religion (2005; Gan Wancang 2006), but the perspective and

\footnotetext{
${ }^{1}$ This paper was inspired by the 2007 conference on "Religion and Social Integration in Chinese Societies" at Chinese University of Hong Kong and particularly the commentary by Karel Dobbelaere. I am grateful for comments from Dai Liyong, Paul Katz, Francine McKenzie, David Ownby and Justin Ritzinger.

${ }^{2}$ Lang (2004) provides a quantitative analysis of this failure of conversation

${ }^{3}$ Obviously, the other papers in this issue do not fall into this category.
} 
purpose are rather different. ${ }^{4}$ Goossaert shows how secularization functions implicitly as a paradigm in the field of Chinese religious studies, while I am interested in the ways that actively relating the two fields may lead to new questions and new insights in both. Can a clearer understanding of concepts, theories and evidence from one field be useful in interpreting those of the other? Does thinking about the history of religion of China help to clarify debates in secularization theory? Does thinking about religious change in comparative terms shed light on the Chinese case? I approach these questions as a scholar of the history of Chinese religions hoping to learn from a related field.

I should make clear at the outset what this paper does not seek to do. First, it is not a summary of the state of religion in China today. It is a discussion of scholarship about religion and policies towards religion, not religion itself. Second, the paper does not seek to defend secularization theory or any particular version thereof. It is a discussion of possible parallels and common concerns between English language scholarship on Chinese religions and sociological writings on secularization. Third, the paper does not address the argument that secularization theory is inseparable from a core meaning of declining religiosity and all versions of secularization theory are ultimately nothing more than attempts to explain this decline. I sidestep this argument by treating various scholarly versions of secularization on their own terms, accepting the position of their authors that their theories seek to explain specific social processes other than religious decline.

In the body of the paper, I single out several elements in debates over secularization theory that seem to me potentially fruitful to the study of Chinese religion. These are: the religious marketplace; the possibility of unbelief; differentiation; patterns of individual religiosity; privatization, and secularization as political ideology. As a means of organizing such a disparate set of themes, the paper is divided into three chronological parts: the early modern period (tenth to nineteenth centuries), the modern period (late nineteenth and twentieth centuries) and the contemporary period (roughly the

\footnotetext{
${ }^{4}$ I learned of Ji Zhe's (2008) impressive assessment of secularization theory too late to make use of in this article.
} 
last thirty years). The logic of this periodization is that secularization theory is ultimately concerned with the relationship between religion and modernity, and in the study of Chinese history the term modernity is generally used in two senses. The first refers to a set of long term changes beginning in the tenth century, including commercialization, urbanization and the growing power of bureaucratic government, and the second to the more rapid changes of the past two centuries. In the third part, I consider how secularization theory might help us better understand state policies towards religion in the People's Republic of China today.

This approach carries several methodological risks. The first is the risk of bias in selection. In this short article, I cannot possibly cover all of the relevant literature in either field. The selection of works discussed must balance suitability for comparison with significance to the field, and this is ultimately determined by my own sense of where the parallels are most fruitful, not any objective criterion. Second, by attempting a cursory summary of work in two fields, one of which is new to me, I risk providing adequate accounts of neither. Third, examining works on Chinese religion in the light of secularization theory risks linking them to an analytical framework that their authors themselves might not accept. I justify the approach on the grounds that the benefits of bringing China into the debates on secularization outweigh the risks.

To an outsider to the field, the range of definitions of secularization in the sociology of religion can be bewildering (Stark and Finke 2000; Swatos and Olson 2000). What all share is the goal of describing the consequences of modernization for religion. According to what might be called the "hard" version of the theory, the main effect of modernization is to cause religion to decline. It was the empirical falsification of this version, the stubborn refusal of large numbers of people around the world to conform to the theory of declining religiosity, that sparked later challenges to the theory. Within sociology, there have been three main responses to these challenges: rejection, limitation, and refinement. 
Scholars who reject secularization theory typically hold that the theory is fundamentally flawed, and that no rigorous theory of secularization is possible (Stark and Finke 2000). They then look for other explanations for religious change. One promising line of argument is the notion of a religious economy or marketplace. While its proponents would likely not label this a form of secularization theory, it is logically and historically derived from it, and might therefore be called post-secularization theory. A second response is to limit the theory to the narrow context in which it was developed. This approach sees secularization as a phenomenon unique to parts of Europe, and of no value in explaining religious change elsewhere (Hervieu-Léger 2001). Others have sought to deal with the empirical challenges to secularization theory by refining the theory while still asserting its general applicability as an explanation of religious change. For example, Dobbelaere (2002) and Casanova (1994) break the concept down into several propositions and evaluate these separately. A fourth set of approaches to secularization comes mainly from disciplines outside sociology. This response holds that secularization is not simply a descriptive theory, but also a political doctrine. The empirical validity of secularization theory becomes irrelevant in this approach; what is important is to explore the origins, development and consequences of secularization as an ideology.

The religious marketplace and the possibilities of unbelief in early modern China

In this section, I discuss briefly two areas of research on religion in early modern China that might fruitfully be considered in relation to developments in secularization theory.

The durability of existing Christian churches in the West and the explosion of new religious movements demonstrated that individual religiosity need not decline as modernization proceeds. Demand for religion exists even among people living in contemporary modern society. Framing the issue in this way suggested the beginnings of a new theory of religious change, that of a religious marketplace characterized by the interaction of supply and demand, in which individuals are actors making rational 
choices. Some scholars of Chinese religion have begun to use this model to discuss religion in contemporary China (Yang Fenggang, 2006). We can also learn something from applying the model to early modern China. Many scholars of Chinese religious history argue that the Chinese situation from the Song dynasty (960-1279) onwards can be described as a market, in which people made choices from a wide range of traditions, ritual practices, and teachings. Actually, this metaphor was not the invention of modern scholars. The extensive commercialization of the Chinese economy during this period meant that people in Song society also thought about religion in precisely these terms (Davis 2001; Hansen 1990; Hymes 2002; von Glahn 2004). Ownby (2003) suggests that we can identify long-term cycles of market opening and closure in China, expressed in the flourishing of popular religion and sectarianism alongside the institutional religions. State efforts to enhance control over institutional religion and the neo-Confucian revival from the Song led to policies restricting the expansion of Buddhism and Daoism. By weakening institutional religions, these created an ecology in which religious alternatives could flourish. DuBois (2005) shows that a second cycle began in the early twentieth century when the destruction of temple-based communal religion led to the expansion of groups known as redemptive societies. Though not framed as such, this argument might be generalized into a supply-side theory of the religious marketplace. State repression of heterodox groups limits their market, but state repression of institutional religion may paradoxically serve to expand it, since non-institutionalized groups are better able to accommodate state pressure. ${ }^{5}$ The existence of a religious marketplace in Song China raises several comparative questions. Was this religious marketplace comparable to contemporary religious pluralism? Can we use pluralism to describe a situation where multiple religious options co-exist with a state whose legitimacy itself rests on religious grounds? The answers to such questions should help us better understand not only Song religion but also the meaning of pluralism.

Was it possible to stand outside the religious marketplace in pre-modern China? Was religious belief understood to be "one option among others"? This is a key

\footnotetext{
${ }^{5}$ This argument can be compared to Stark's (1987) set of factors affecting the success of New Religious Movements.
} 
proposition in Taylor's efforts to refine the concept of secularization $(2007,3){ }^{6}$ Western scholars since the Jesuits have described the Chinese people and particularly their social and intellectual elites as secular rationalists. Recent research on the religious and ritual dimensions of Confucianism and the state cults and the engagement of the literati elite with other elements of the religious marketplace undermines this position (Davis 2001; Boltz 1993; Szonyi 1997). Thus whereas scholars of Europe now question whether there ever was a past "Age of Faith", scholars of China now question whether there ever was an "Age of Faithlessness". 7 Sutton (2000) identifies a process "from credulity to scorn" in elite understandings of one important dimension of religious life, ritualized possession by spirits. But this shift away from believing in mediumism took place from within rather than outside the broad understandings of the religious world. Mediums were charlatans and troublemakers, thought late imperial intellectuals, but this did not mean that there were not spirits and ghosts, simply that the mediums did not have access to them. It was only much later that Chinese elites began to criticize Chinese religion from a position outside it (Goossaert 2006). Thus while the process whereby the possibility of unbelief first appears among elites and later diffuses through the broader population may be found in societies outside the West, the mere existence of elite criticism of popular religion is not evidence of this process. Elite criticism of popular religion, found widely in different societies, is different from the possibility of unbelief. The appearance and spread of unbelief is a historical process that will vary from society to society, and therefore should also be studied comparatively.

Secularization and the Creation of Religion in Modern China: Differentiation

\footnotetext{
${ }^{6}$ The point, if I understand Taylor correctly, is not simply a shift from belief to unbelief. Rather, Taylor is suggesting that secularization means unbelief becomes a legitimate, public position.

${ }^{7}$ This position is not universally accepted, especially among Chinese scholars. Wang and Zou (2004) is an example of recent work arguing that Chinese society has always been secular.
} 
In this section, I review some of the literature on religion in China since the onset of more rapid changes in the nineteenth century. Again, my goal is not to summarize this history but to point out interesting points of intersection with secularization theory. The focus is on successive regimes on the mainland, though I touch briefly on Taiwan.

One common element among scholars who seek to refine secularization theory is the notion of differentiation or autonomization. For Casanova, this is the "functional differentiation and emancipation of the secular spheres - primarily the state, the economy, and science - from the religious sphere and the concomitant differentiation and specialization of religion within its own newly found religious sphere" $(1994,19)$. It is obvious that at a certain level differentiation has occurred in modern China. The state's legitimacy and the people's well-being no longer rest on the performance of rituals by the emperor and his officials. But the Chinese case shows that the process of differentiation depends on the specific conditions of the society.

The theoretical literature often distinguishes between two types of differentiation - latent and deliberate (Dobbelaere 2002, 19). ${ }^{8}$ In the China field, we can trace a shift in emphasis from one to the other. C.K. Yang (1961) and Seiwert (1981) treated differentiation as a latent function of modernization, as the inevitable by-product of industrialization, urbanization, and so on. Recent works see differentiation more as a deliberate policy. In Europe, the secularization process involved the differentiation of an ever-expanding secular realm from the religious. In China the differentiation of secular from religious also involved the creation in the early twentieth century of a new category of religion. ${ }^{9}$ The secularization of China was thus also the religionization of China (Weller 2008). Aimed at bringing about the fundamental transformations that would lead to modernity, it was a project in some ways as utopian as the religions it sought to categorize and regulate.

\footnotetext{
${ }^{8}$ Deliberate secularization is also referred to as forced secularization (Froese 2004).

${ }^{9}$ A recent effort (Yu 2005) to show that the term has a longer pedigree is unconvincing. Chen (2002) shows that while the term may have appeared in antiquity, its current usage developed in the past century. Of course, the meaning of the term in Western languages has hardly been static either.
} 
The construction of religion as a category or concept relied heavily on European ideas and the model of Christianity. A religion was a formally constituted social organization associated with a body of written doctrine that expressed both a cosmology and an ethical system. State and elite attitudes towards religious groups came to be shaped by the degree to which a group conformed to this definition. National Buddhist, Daoist, Muslim and Confucian associations soon formed, seeking to reinvent their traditions along the lines of European churches. This meant organizing as hierarchical institutions overseeing professional clerics and engaging in activities seen as appropriate to religion: religious training, ritual performance, charitable works, and so on, with recognition from the state. The Buddhist response to this top-down invention of religion has been well studied (Welch 1968); that of other groups less so. Confucianism was ultimately denied status as a national religion by the Republican parliament, a clear indication of the politicization of the project of inventing Chinese religion.

With religion narrowly defined in terms of a small number of organized national churches, the temple worship that characterized the religious life of vast numbers of people became defined out of the category of religion, relegated instead to the also newly created category of superstition (mixin). Much recent work on Chinese religion in the early twentieth century shows that this process of differentiation between religion and superstition complicates any theory of differentiation between religion and other spheres. Nedostup (forthcoming) and Duara (1995) show that differentiation inevitably forced the state into the position of arbiter of religion. Goossaert (2006) and Poon (2004) show that intervention was a material as well as intellectual and political process, with the state, its agents and local elites laying claim to temple property. These authors all address the issue of the relationship of the state to religion and state efforts to create a secular society as part of the transition to modernity. The process of differentiation they describe was more complex than simply the separation of church and state. Secularization in China was a dual movement of distinction and intervention, to distinguish religion from superstition and to reshape those aspects of religious life that did meet the new criteria to make them better serve state agendas. Differentiation meant the deliberate construction of a religious sphere by elites and the state and corresponding responses by religious 
groups. The new categorization scheme was deployed by a state whose legitimacy, indeed whose whole raison d'etre, was modernization. Once secularization became central to modernity, then modernity became impossible without secularization.

These works on China suggest parallels with that of Asad (1993, 2003). Building on Taylor's claim that secularization is crucial to the legitimacy of the nation-state since the state must be secular if its legitimacy is to be independent of religious grounds, Asad argues that the modern notion of a secular society implies a distinctive relationship between the state and personal morality, in which religion is restricted, or differentiated, to a specific domain. Asad shows that in the history of the West religion and politics are thus inevitably implicated with, even mutually constitutive of, one another. One could therefore read Asad as a challenge to the differentiation thesis. ${ }^{10}$ Both Asad's work and the China research challenge secularization theory to explore how the relationship between politics and religion has developed historically in different contexts. Both bodies of work question the very possibility of differentiation, and, to the extent that it is possible, whether differentiation can ever be a latent as opposed to a deliberate process.

The post-Mao religious revival, individual religiosity and privatization

In order to concentrate on the contemporary period, I make only two brief comments on the early PRC or Maoist period from 1949 to 1976. First the PRC inherited and perpetuated many of the assumptions about and agendas towards religion as its predecessor. Five officially recognized religions were reorganized as hierarchically structured national bodies under the control of state organs, thereby ensuring that they would continue to be constituted politically. Second, as is well known, the Cultural Revolution period saw the brutal suppression of religion in China, both religion as defined by the state and the superstition that lay beyond the bounds of the definition. In this period the relationship between the state and religion was, while highly repressive, relatively straightforward. Barmé (1996), Feuchtwang (2002), Feuchtwang and Wang

\footnotetext{
${ }^{10}$ Also see Tambiah (1990). Asad's relevance to China is explored from another perspective by Kipnis (2001).
} 
(2001), ter Haar (1996-1997) and Zuo (1991) have however pointed out the degree to which religious themes such as millenarianism and exorcism pervaded Maoism, suggesting in other words that Maoism might be seen as civil or political religion. Since 1976 new complexities have appeared, both with the huge expansion in the practice of religion and in the state responses. Below, I single out two ways in which the study of religion in the reform era might be related to secularization theory: the issue of individual religiosity and privatization.

Most of the controversy around secularization theory is located at the micro level of individual religious involvement. The expansion in religious activity in the PRC since the 1980s is an obvious empirical challenge to the idea that modernity means the decline of religion (Overmyer 2003; Fan 2003; Madsen 2007). With millions of adherents in its short history that dates back only to 1982, Falungong may qualify as one of the most rapid expansions of religiosity in world history. (Palmer (2007) and Ownby (2008) make clear that it should be considered a religious movement). But recent sociological literature is already skeptical of the "hard" version of secularization. We can distinguish two broad approaches to the refining of this element of the theory. Some scholars recognize the possibility that individuals may continue to be religious but hold that individuals become more secular in their devotion. They focus on good works and ethical conduct rather than salvation, on the social rather than spiritual dimensions of religious involvement. In China, Ownby (2008) and Palmer (2007) trace a trajectory of Falungong that is the opposite of this trend, from a secular to a more religious ideology, including apocalyptic, messianic and exclusive themes. Within Christianity, in China as elsewhere, the proposition of secularizing individual religiosity has also not been born out empirically. Emotionally intense and charismatic forms of worship, exorcism, faithhealing and miracles remain central to the religious lives of many Chinese Christians, including new converts (Madsen 2001, Bays 2003, Dunn 2009). ${ }^{11}$ A second approach within secularization theory holds that the distinguishing feature of modern religiosity is the autonomy of individuals to construct their own religious world. Research on the bricolage of religiosity in the new city of Shenzhen supports this argument (Fan et al

${ }^{11}$ Also see Rubinstein (1991) on Christian groups in Taiwan. 
2004), but as we have seen above in China this sort of personal religious world is not a purely modern phenomenon but was also present historically.

Besides questions about the empirical validity of the propositions of secularization theory, the Chinese case also offers a more fundamental challenge to theories about individual religiosity, for the measures chiefly used to assess individual religiosity are not easily transferred to China. Much sociological analysis of Chinese religion, which typically tests the extent of religious conceptions (believing) or institutional affiliations (belonging), therefore strikes specialists in Chinese religion as missing the point. Neither church attendance nor survey-based assessments of individual beliefs have much meaning for Chinese aside from Christians and Muslims. Practice ("doing", to use Chau's term (2006)), meaning participation in individual and communal rituals, is a more defining element of Chinese religion. Here again we see the mismatch of the Enlightenment-derived definition of religion with the situation in China. It is not just that the key measures of individual secularization vary across contexts, but the very measures themselves turn out on closer analysis to be culturally specific rather than universal. $^{12}$

I turn now to the issue of privatization. Casanova seeks to refine secularization theory by breaking it down into three distinct propositions: decline, differentiation, and privatization. His main focus is to challenge the third of these propositions. Since the 1980s religious institutions and traditions around the world have demanded public and political roles. Critics of secularization theory argue that this is further proof that the theory is false. Casanova responds that privatization of religion is not necessarily associated with modernity, that there exists the possibility of a public role for religion that is consistent with the requirements of a modern society. Casanova $(1994,66)$ calls this deprivatization, "the process whereby religion abandons its assigned place in the private sphere and enters the undifferentiated public sphere of civil society to take part in

\footnotetext{
${ }^{12}$ Reed (2007) illustrates the problem of trying to evaluate religiosity across cultures without attending to differences in the meaning of religion.
} 
the ongoing process of contestation, discursive legitimation, and redrawing of the boundaries."

Much recent literature on Chinese religion actually speaks to similar themes without engaging explicitly with this approach. The issue has often been framed in terms of debates about civil society. In the 1990s, interest in the potential political roles of groups organized around religious ritual led to discussion about whether religion constituted a public sphere in late imperial China (Dean 1997). Religion in Taiwan has come to play an important public political role, basically corresponding to Casanova's notion of deprivatization. In the period of martial law from the $1950 \mathrm{~s}$ to the $1980 \mathrm{~s}$, popular religion became a way that Taiwanese identity was constituted against the KMT regime that had moved to the island from mainland China in 1949. Weller's work shows that religious ritual became a forum for commentary on and challenge to politics (Katz 2003; Weller 1985, 2004). Since liberalization and democratization, religious groups have repeatedly mobilized openly for political action, often in support of environmental causes. Weller $(2004,296)$ thus notes that while religion was not crucial in the democratization process, it is "central" to successful democracy. This argument could easily be rephrased in terms of the public role or deprivatization of religion.

What about the PRC? Weller $(2004,313)$ concludes his discussion of deprivatized religion in Taiwan with the provocative suggestion that it may one day have a similar role on the mainland. "Chinese popular worship provides one of the major building blocks of local society, and it therefore can play a central role in the realization and consolidation of any democratic opening." But Weller's own research shows that the deprivatization of religion is not dependent on democratization. In the PRC at the local level Chau (2006), Dean (2003) and Eng and Lin (2002) show how communal temples already play a political role. In the Mazu pilgrimages from Taiwan to the mainland, Mayfair Yang $(2004,228)$ sees a form of deprivatization "delineating the contours of a new matrifocal transnational ritual community" that challenges the national imaginary of the secular state. The most openly deprivatized religious group in the PRC is Falungong. Its politicization since 1999 is at one level an effort to defend its turf. But at the same 
time, it is also an example of Casanova's deprivatization, a claim "to participate in the very struggles to define and set the modern boundaries between the private and public spheres, between system and life-world, between legality and morality, between individual and society" $(1994,6)$.

Secularization theory and party-state discourses on religion

How do theories of secularization affect policies towards religion today? I am interested here not in theories of secularization developed and articulated by scholars, but those held explicitly or implicitly by political elites, who use these ideas in formulating policy. Official policies towards religion in China have been summarized by Potter (2003), Leung (2005), Ying (2006), and Ownby (2009). In this section, I suggest that analyzing recent shifts in policies in relation to ideas about secularization can be useful to understanding the changes.

With the campaign against Falungong generating a new pattern of differentiation, between religion, superstition and evil cult, state intervention in religious matters has in some ways grown in recent years ( $\mathrm{Fu} 2003$ ). Concerned about possible links between religion, ethnic minorities and territorial security, the PRC is also intervening in new ways in Islam and Tibetan Buddhism, most recently by asserting authority over the recognition of reincarnate lamas. But recent official statements also suggest the possibility of a more accommodating religious policy. Pan Yue (2001) calls on the regime to take advantage of the "unifying power and appeal of religion" to serve CCP interests. Senior leaders have repeatedly called for the management of religion to be incorporated into the larger programs of "harmonious society" and "scientific development". The head of the State Administration of Religious Affairs Ye Xiaowen (2008) summarizes this shift in the party's overall position. "A clear path of change lies before us: from viewing religion in a chiefly negative light, to objectively viewing 
religion as having both positive and negative capabilities, and finally to looking at religion from a positive angle and emphasizing its positive functions." ${ }^{, 13}$

Beneath this apparent paradox of tighter control and positive evaluation lie continuities in leadership thinking about religion and secularization. The PRC leadership has, publicly at least, undergone a basic shift away from the "hard" version of secularization. But it continues to reject the notion of differentiation in the sense that religion should be confined to its own autonomous sphere. The CCP retains absolute authority to determine both what constitutes religion and what activities are appropriate to religion. Consistent with elite attitudes towards secularization that date back a century or more, the religious sphere is a sphere to be determined, regulated, and co-opted by the state. Though willing to allow religious organizations to participate in public life through the provision of social services, the state retains absolute authority over any such deprivatization. The regime remains committed to, in Ownby's (2009) phrase, "secularization with Chinese characteristics."

Two interesting consequences result. Regardless of whether one adopts a functional or substantive definition of religion, vast realms of the Chinese religious landscape are not formally constituted as religion. Besides groups that are labelled as evil cults and banned, the temple worship, devotional societies and healing and prognostication traditions found throughout rural China are not considered religion because they do not meet the official criteria. Yang Fenggang (2006) uses the terms black market and gray market to describe these phenomena, the latter denoting "all religious and spiritual organizations, practitioners, and activities with ambiguous legal status." Under current policies, these two markets will remain a significant part of overall religious life. Second, many religious devotees themselves have come to accept

\footnotetext{
${ }^{13}$ This position is echoed in some recent scholarly works on religion. He Yanfeng $(2008,4)$ writes that religion is a "powerful force that impacts economic development, political stability, and national unity and that cannot be neglected." I have deliberately chosen not to address the (small) literature on secularization among PRC scholars of Chinese religion. The state of the field is discussed in Yang (2004). From my cursory analysis, most seem to use the term secularization simply to refer to changes that have occurred in religion as a result of the introduction of reform. Thus for He (2008) secularization (shisuhua) means that religious organizations become involved in secular activities such as education and charity. He is thus using secularization to mean what scholars writing in English describe as desecularization.
} 
the state monopoly on defining religion. Thus participants generally describe temple worship not as religious but as "popular culture" (minjian wenhua), "folk culture" (minsu wenhua) or even "superstition" (mixin). To use Yang's terminology, adherents of Chinese popular religion deliberately position themselves in the gray market so as to avoid being labelled in the black market.

While this very brief account does not do justice to the complexities of contemporary Chinese religious policies, it does make clear that secularization needs to not only as a tool but also as an object of analysis, not only a descriptive theory but also a political ideology or doctrine. It also suggests a further agenda for comparative research, namely the study of how ideologies of secularization have developed over time among ruling elites in different countries, and how those ideologies have shaped religious policies and religious responses. In other words, a comparative history of policies of secularization is needed.

\section{Conclusions}

I hope this discussion has shown that despite their lack of dialogue, the study of Chinese religion and secularization theory share some common ground. For any version of secularization theory to claim general validity, it must account for China. Certainly quantitative studies that make global claims are quite irrelevant if they do not take the Chinese data, and the peculiarities of measuring that data, into account. But more fundamentally, thinking about China is helpful in challenging the "hegemony of the mainstream master narrative of secularization" (Taylor 2007, 534), illustrating the provincialism of theoretical approaches grounded in the Western experience and exposing the range of alternative possibilities. Secularization theory arose as part of the Enlightenment critique of religion. Applying it to China helps us explore the question of whether the theory can be separated from that critique, and whether secularization as a theoretical account of religious change is viable. 
To summarize the findings above, we can find in the Chinese material relevant to each of the four main responses to the challenges to secularization: rejection, limitation, refinement and study of secularization as political doctrine. For those who reject secularization and propose its replacement with a religious economy approach, the Chinese case shows that a religious marketplace is not unique to modern society. For those who argue for the refining of secularization theory, the Chinese case shows that differentiation need not imply the separation of the state from religion but rather a new kind of intervention. The Chinese case shows that secularization as differentiation can be a deliberate rather than latent process. Lastly the Chinese case shows the importance of considering secularization as an ideology whose origins and effects should be traced historically.

As political doctrine secularization was hardly unique to Europe. This is the strongest argument against the limitation response. Throughout the non-Western world secularization as political discourse was tied to anti-colonial nationalism and the legitimizing efforts of new nation-states. Secularization was in a sense really a form of Westernization. It meant the adoption of a definition of religion derived from the West, and the remaking of religious life to conform to that definition. Closely tied to the projects of modernity and the making of the nation-state, secularization in China is therefore an exemplar of what Chatterjee (1986) calls the derivative discourse of anticolonial nationalism. The problem of Chinese religion emerged out of arguments about Chinese deficiency that were first devised by the colonial powers. The premises of these arguments had to be accepted by nationalist modernizers in order to turn them back against imperialism and legitimize their own modernizing projects to their populations. One of the key questions that emerges out of this recognition is whether there are common patterns of variation in colonial and non-European societies arising from this fact. How are such patterns produced by the historical relationship of the state and religion, and how by the nature of the encounter with European expansion?

Turning the question around, the study of Chinese religion would benefit also from comparison with the constitution of religion across all world societies. In other 
words, a theory of Chinese secularization would encourage placing the history of Chinese religion in the global context of the reinterpretation of religion in response to the globalization of European ideals. Recognizing that secularization even in its more restrictive forms is a highly contingent process will shape other debates as well. For example, it becomes evident that it is unproductive to discuss issues such as whether or not there is religious freedom in China without attending to the historical process through which the notion of religious freedom emerged there. The standard by which state policy towards religion is judged is inevitably linked to how the legitimate exercise of power is constituted. In contemporary China, this standard is not respect for individual rights alone but also the pursuit of nationalism and modernization. Given that China's rulers have wholeheartedly accepted the assumption, derived from the West, that secularization is central to modernity, is it any wonder that religion has become a target of political intervention? Given the challenges to this assumption, is it any wonder that this intervention is the source of tension both within and beyond the nation? (Comaroff 1994). And given some of the deleterious consequences of the single-minded rush to modernization that are now becoming evident, and the recognition that these consequences may undermine the legitimacy of the regime, is it any wonder that there has been a recent turn to a more positive evaluation of religion as an element contributing to social stability and a more "harmonious society"?

To look at the last century of history of Chinese religion in the context of secularization theory is to see it neither as a unique phenomenon nor as a case study of the universal processes of modernity, but rather as one example of how states and religions around the world have responded to the imposition of the hegemonic master narrative of Western modernity. The hard forms of secularization theory do not work very well to explain the history of religion in China (indeed, they turn out not to work very well elsewhere either). But more restricted theories of Chinese secularization enable us to better see that despite the vast differences in the history and contemporary expression of world religions, secularization processes around the world are linked in fundamental ways. 
References

Asad, Talal (1993). Genealogies of Religion: discipline and reasons of power in Christianity and Islam. Baltimore: Johns Hopkins Univ. Press

(2003). Formations of the Secular: Christianity, Islam, Modernity. Stanford: Stanford Univ. Press.

Barmé, Geremie (1996). Shades of Mao: The Posthumous Cult of the Great Leader. Armonk, NY: M.E. Sharpe.

Bays, Daniel (2003). “Chinese Protestant Christianity Today.” China Quarterly 174: 488504.

Beckford, James (2003). Social Theory and Religion. Cambridge: Cambridge Univ. Press.

Boltz, Judith (1993). " Not by the Seal of Office Alone: New Weapons in Battles with the Supernatural." In Patricia Ebrey and Peter Gregory, eds. Religion and Society in T'ang and Sung China. Honolulu: Univ. of Hawaii Press.

Casanova, José (1994). Public Religions in the Modern World. Chicago: Univ. of Chicago Press.

Chatterjee, Partha (1986). Nationalist Thought and the Colonial World: a Derivative Discourse? London: Zed.

Chau, Adam Yuet (2006). Miraculous Response: Doing Popular Religion in Contemporary China. Stanford: Stanford Univ. Press.

Chen Hsi-yuan (Chen Xiyuan) (2004). 'Zongjiao' - yige Zhongguo jindai wenhuashi shang de guanjian ci ['Religion' - a critical term in Chinese modern cultural history]." Xin Shixue, 13.4: 37-66.

Comaroff, Jean (1994). "Defying Disenchantment.” In Charles Keyes, Laurel Kendall and Helen Hardacre, eds. Asian Visions of Authority: Religion and the Modern States of East and Southeast Asia. Honolulu: Univ. of Hawai'i Press.

Davis, Edward L. (2001). Society and the Supernatural in Song China. Honolulu: Univ. of Hawai'i Press.

Dean, Kenneth (1997). "Ritual and Space: Civil Society or Popular Religion?” In Timothy Brook and B. Michael Frolic, eds. Civil Society in China, Armonk, NY: M.E. Sharpe. (2003). "Local Communal religion in Contemporary South-east China." China Quarterly 174 (June): 338-358.

Dobbelaere, Karel (1981/2002). Secularization: An Analysis at Three Levels. P.I.E.-Peter Lang, Brussels.

Duara, Prasenjit. (1995). Rescuing History from the Nation: Questioning Narratives of Modern China. Chicago: Univ. of Chicago Press

DuBois, Thomas (2005). The Sacred Village: Social Change and Religious Life in Rural North China. Honolulu: Univ. of Hawai'i Press.

Dunn, Emily (2009). "CCult," Church, and the CCP: Introducing Eastern Lightning." Modern China 35: 96-119.

Eng, Irene, and Yi-Min Lin (2002). "Religious Festivities, Communal Rivalry, and Restructuring of Authority in Rural Chaozhou, Southeast China." Journal of Asian Studies 61.4: 1259-1285. 
Fan Lizhu (2003). "Popular Religion in Contemporary China." Social Compass 50.4: 449-457.

Fan Lizhu, James Whitehead \& EvelynWhitehead (2004). "Fate and Fortune: Popular Religion and Moral Capital in Shenzhen." Journal of Chinese Religions 32: 83100.

Feuchtwang, Stephan (2000). "Religion as resistance.” In Elizabeth Perry and Mark Selden, eds. Chinese Society. Change, Conflict and Resistance. London: Routledge.

Feuchtwang, Stephan and Wang Mingming (2001). Grassroots Charisma: Four local leaders in China. London: Routledge.

Froese, Paul (2004). "Forced Secularization in Soviet Russia: Why an Atheistic Monopoly Failed." Journal for the Scientific Study of Religion. 43.1: 35-50.

Fu Xiqiu, ed (2003). Religious Freedom and Rule of Law. Special issue of Chinese Law and Government. 36.2.

Gao Wancang [Vincent Goossaert] (2006). "Xiandai Zhongguo de guojia yu zongjiao: zongjiao zhengce yu xueshu dianxing [State and Religion in Modern China: Religious Policies and Scholarly Paradigms]." Zhongyang yanjiuyuan jindaishi yanjiusuo jikan. 54:169-209.

Goossaert, Vincent (2005). "State and Religion in Modern China: Religious Policies and Scholarly Paradigms." Paper presented at the International Conference on the $50^{\text {th }}$ Anniversary of the Institute of Modern History, Academia Sinica, Taipei. (2006). "1898: The Beginning of the End for Chinese Religion?" Journal of Asian Studies 65.2: 307-335.

Hansen, Valerie (1990). Changing Gods in Medieval China, 1127-1276. Princeton: Princeton University Press

He Yanfeng (2008). Dangdai Zhongguo zongjiao wenti de wenhua yanjiu [Cultural research into the religious question in contemporary China]. Changchun: Jilin daxue.

Hervieu-Léger, Danièle (2001). "The twofold limit of the notion of secularization." In Linda Woodhead et al, eds. Peter Berger and the study of religion. New York: Routledge.

Hymes, Robert (2002). Way and byway: Taoism, local religion and models of divinity in Sung and modern China. Berkeley: Univ. of California Press.

Ji Zhe (2008). "Ruhe chaoyue jingdian shisuhua lilun? [How to transcend classical secularization theory?]." Shehuixue yanjiu. no. 4: 55-75.

Katz, Paul (2003). "Religion and the state in post-war Taiwan." China Quarterly 174: 395-412.

Kipnis, Andrew (2001). "The Flourishing of Religion in Post-Mao China and the Anthropological Category of Religion." Australian Journal of Anthropology. 12.1: 32-46.

Lang, Graeme (2004). "Challenges for the Sociology of Religion in Asia," Social Compass. 51.4: 99-110.

Leung, Beatrice (2005). "China's Religious Freedom Policy: The Art of Managing Religious Activity." China Quarterly 184: 894-915. 
Madsen, Richard (2001). "Beyond Orthodoxy: Catholicism as Chinese Folk Religion." In Stephen Uhalley and Xiaoxin Wu, eds. China and Christianity: Burdened Past, Hopeful Future. Armonk, NY: M.E. Sharpe. (2007). Democracy's Dharma: Religious Renaissance and Political Development in Taiwan. Berkeley: Univ. of California Press.

Nedostup, Rebecca (forthcoming). Superstitious Regimes: Religion and the Politics of Chinese Modernity.

Overmyer, Daniel (2003). "Religion in China Today: Introduction." China Quarterly. 174: $307-316$.

Ownby, David (2003). "A History for Falun Gong: Popular Religion and the Chinese State Since the Ming Dynasty." Nova Religio 6.2: 223-243. (2008). Falun Gong and the Future of China. Oxford: Oxford Univ. Press. (2009). "Religious Revival and the Rule of Law in China: An Evaluation of 'Secularization with Chinese Characteristics,"' Paper presented at the Conference on Political Change in China, University of Toronto.

Palmer, David (2007). Qigong Fever: Body, Science, and Utopia in China. New York: Columbia Univ. Press.

Pan Yue (2001)."Makesi zhuyi zongjiao guan bixu yu shi jujing [The Marxist perspective on religion must keep in step with the times]." Huaxia Shibao Dec. 15.

Poon, Shuk-Wah (2004). "Refashioning Festivals in Republican Guangzhou." Modern China 30.2: 199-227.

Potter, Pittman (2003). "Belief in Control: Regulation of Religion in China." China Quarterly 174: 317-337.

Reed, Steven (2007). “Analyzing Secularization and Religiosity in Asia.” Japanese Journal of Political Science 8:327-339.

Rubinsten, Murray (1991). The Protestant community on modern Taiwan: mission, seminary, and church. Armonk, NY: M.E. Sharpe

Seiwert, Hubert (1981). "Religious response to modernization in Taiwan." Journal of the Hong Kong Branch of the Royal Asiatic Society 21: 43-70.

Stark, Rodney (1987). "How religious movements succeed: a theoretical model." In David Bromley and Phillip Hammond, eds. The Future of New Religious Movements. Macon, Ga: Mercer Univ. Press.

Stark, Rodney and Roger Finke (2000). Acts of Faith: Explaining the Human Side of Religion. Berkeley: Univ. of California Press.

Sutton, Donald (2000). "From Credulity to Scorn: Confucians Confront the Spirit Mediums in Late Imperial China." Late Imperial China 21.2: 1-39.

Swatos, William and Daniel Olson, eds (2000). The Secularization Debate. Lanham, Md: Rowman and Littlefield.

Szonyi, Michael (1997). "The Illusion of Standardizing the Gods: The Cult of the Five Emperors in Late Imperial China." Journal of Asian Studies 56..:113-135.

Tambiah, Stanley (1990). Magic, science, religion and the scope of rationality. Cambridge: Cambridge Univ. Press.

Taylor, Charles. (2007). A Secular Age. Cambridge, MA.: Belknap Press.

Ter Haar, Barend (1996-1997). "China's Inner Demons: the political impact of the demonological paradigm." China Information 11.2-3: 54-88. 
von Glahn, Richard (2004). The Sinister Way: The Divine and the Demonic in Chinese Religious Culture. Berkeley: Univ. of California Press.

Wang Chuhui and Zou Qianjiang (2004). "Zhongguo he xifang shehui shisuhua jincheng de bijiao [Comparison of the course of secularization in China and Western society]." Renwen zazhi. no. 4: 161-166

Welch, Holmes (1968). The Buddhist Revival in China. Cambridge, MA: Harvard Univ. Press.

Weller, Robert (1985), "Bandits, Beggars, and Ghosts: The Failure of State Control over Religious Interpretation in Taiwan." American Ethnologist 12.1:46-61. (2004). "Worship, Teachings and State Power in China and Taiwan." In William Kirby ed, Realms of Freedom in Modern China. Stanford: Stanford Univ. Press. (2008). "Religion and State Across the Strait." Paper presented at the Worshop on Formative Dialectics: New Perspectives on Cross-Straits Relations, UC Berkeley.

Yang Fenggang (2004). "Between Secularist Ideology and Desecularizing Reality: The Birth and Growth of Religious Research in Communist China." Sociology of Religion 65.2: 101-19 (2006). "The Red, Black, and Gray Markets of Religion in China." Sociological Quarterly 47: 93-122.

Yang, C.K. (1961). Religion in Chinese Society. Berkeley: Univ. of California Press. Yang, Mayfair Mei-hui (2004). "Goddess Across the Taiwan Strait: Matrifocal Ritual Space, Nation-state, and Satellite Television Footprints.” Public Culture 16.2: 209-238.

Ye Xiaowen (2008). " 'Yiren weiben' shenru zongjiao [Taking the person as the core to deeply engage with religion]." Zhongguo zongjiao no 3: 10-13.

Yu, Anthony (2005). State and Religion in China: Historical and Textual Perspectives. Chicago: Open Court.

Ying, Fuk-Tsang (2006). "New Wine in Old Wineskins : An Appraisal of Religious Legislation in China and the Regulations on Religious Affairs of 2005." Religion, State and Society 34.4: 347-373.

Zuo, Jiping (1991). "Political Religion: The Case of the Cultural Revolution in China." Sociological Analysis 52.1: 99-110. 